\title{
A revision of Sunius XVI. Two new species from Iran and Iraq (Coleoptera: Staphylinidae: Paederinae)
}

With 10 figures and 2 maps

\section{VOLKER ASSING ${ }^{1}$}

${ }^{1}$ Gabelsbergerstraße 2, 30163 Hannover, Germany. - vassing.hann@t-online.de

Published on 2017-12-08

DOI: $110.21248 /$ contrib.entomol. $67.2 .247-2533_{1}^{\prime}$

\section{Abstract}

Two species of Sunius STEPHENs, 1829 are described and illustrated: S. reuteri spec. nov. (North Iraq), the first record of the genus from Iraq, and S. concurvatus spec. nov. (South Iran). Additional records of six previously described species are reported from the West Palaearctic region. Updated distribution maps are provided for S. khnzoriani (Coiffait, 1970) and S. fulgocephalus (Coiffait, 1970). The genus is currently represented in the Palaearctic region by 138 described species and two subspecies.

\section{Nomenclatural acts}

Sunius reuteri spec. nov. -urn:lsid:zoobank.org:act:2E7291CB-C82F-4970-80A2-CD2134094330,

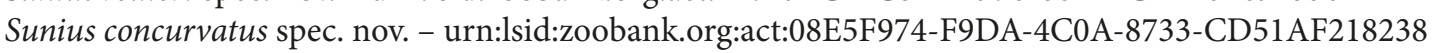

\section{Key words}

Coleoptera, Staphylinidae, Paederinae, Medonina, Sunius, Palaearctic region, Iraq, Iran, taxonomy, new species, new records, distribution maps

\section{Zusammenfassung}

Zwei Arten der Gattung Sunius Stephens, 1829 werden beschrieben und abgebildet: S. reuteri spec. nov. (Nord-Irak), der erste Nachweis der Gattung aus dem Irak, und S. concurvatus spec. nov. (Süd-Iran). Weitere Nachweise von sechs beschriebenen Arten werden aus der Westpaläarktis gemeldet. Für S. khnzoriani (CoIfFAIT, 1970) und S. fulgocephalus (CoIfFAIT, 1970) werden aktualisierte Verbreitungskarten erstellt. Die Gattung ist derzeit mit 138 beschriebenen Arten und zwei Unterarten in der Paläarktis vertreten.

\section{Introduction}

According to the latest contribution to the revision of Sunius Stephens, 1829, the genus was represented in the Palaearctic region by 126 species and two subspecies
(Assing 2015). In the meantime, ten additional species have been described from Turkey (ANLAş 2015a-b, 2016a-b) and the Greek island Lesbos (Assing 2016). 
A catalogue and a key to species were provided by Assing (2011). While eight Sunius species were previously known from Iran, two of them exclusive, the genus had never been recorded from Iraq.

The present paper is based on new material studied since the previous contribution. It includes two new species from Iran and Iraq.

\section{Material and methods}

The material treated in this study is deposited in the following collections:

MNB Museum für Naturkunde Berlin (incl. coll. Schülke; J. Frisch, M. Schülke

NME Naturkundemuseum Erfurt (M. Hartmann)

NMP National Museum of Natural History, Praha (J. Hájek)

cAss author's private collection

cKoc private collection Matúš Kocian, Praha

The morphological studies were conducted using a Stemi SV 11 microscope (Zeiss Germany) and a Jenalab compound microscope (Carl Zeiss Jena). The images of external characters were created using a photographing device constructed by Arved Lompe (Nienburg) and CombineZ software. A digital camera (Nikon Coolpix 995) was used for the remaining photographs.

Body length was measured from the anterior margin of the mandibles (in resting position) to the abdominal apex, the length of the forebody from the anterior margin of the mandibles to the posterior margin of the elytra, head length from the anterior margin of the frons to the posterior constriction of the head, elytral length at the suture from the apex of the scutellum to the posterior margin of the elytra (at the suture), and the length of the aedeagus from the apex of the ventral process to the base of the aedeagal capsule. The "parameral" side (i.e., the side where the sperm duct enters) is referred to as the ventral, the opposite side as the dorsal aspect.

\section{Descriptions and additional records}

\section{Sunius propinquus (BRISOUT DE BARNEVILLE, 1867)}

Material examined: Spain: Andalucía: 2 exs., Cádiz, East Facinas, Embalse de Almodóvar, $36^{\circ} 09^{\prime} \mathrm{N}, 5^{\circ} 38^{\prime} \mathrm{W}$, 120 m, under stones, 5.I.2017, leg. Forcke (MNB); 1 ex., Cádiz, S Benalup-Casas Viejas, Embalse del Celemin, $36^{\circ} 19^{\prime} \mathrm{N}, 5^{\circ} 46^{\prime} \mathrm{W}, 30 \mathrm{~m}$, under stones, 28.XII.2016, leg. Forcke (MNB); 10 exs., Cádiz, Zahara de los Atunes, $36^{\circ} 08^{\prime} \mathrm{N}, 5^{\circ} 51^{\prime} \mathrm{W}, 1 \mathrm{~m}$, beach, under debris and stones, 29.XII.2016-6.I.2017, leg. Forcke (MNB); 1 ex., Cádiz S San Roque-Sotogrande, $36^{\circ} 16^{\prime} \mathrm{N}, 5^{\circ} 17^{\prime} \mathrm{W}, 1 \mathrm{~m}$, beach, under debris and stones, 1.I.2017, leg. Forcke (MNB).
Comment: Sunius propinquus, the most common representative of the genus in Spain, has an AtlantoMediterranean distribution. For a map see Assing (2008).

\section{Sunius simoni (OUEDENFELDT, 1881)}

Material examined: Spain: Andalucía: 1 ex., Cádiz, East Facinas, Embalse de Almodóvar, 3609'N, 5³8'W, 110 m, under stones, 3.I.2017, leg. Forcke (MNB).

Comment: Sunius simoni is endemic to the extreme south of Spain and North Morocco. Its distribution is mapped in Assing (2008).

\section{Sunius khnzoriani (CoIfFAIt, 1970) \\ (Map 1)}

Material examined: Armenia: 1 ㅇ, $40 \mathrm{~km}$ NW Sisian, W-side of Vorotan Pass, 39 43'N, 4540'E 1960 m, dry oak forest, litter and roots sifted, 30.VI.2016, leg. Assing

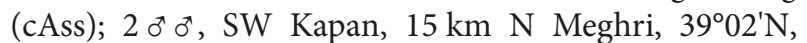
$46^{\circ} 12^{\prime} \mathrm{E}, 1680 \mathrm{~m}$, road margin, under stones, 6.VII.2016, leg. Assing (cAss); $10^{7}, 4$ ㅇ ㅇ , 17 exs., SW Kapan, $10 \mathrm{~km} \mathrm{~N}$ Meghri, $38^{\circ} 59^{\prime} \mathrm{N}, 46^{\circ} 11^{\prime} \mathrm{E}, 1350 \mathrm{~m}$, slope with oak, other trees, and bushes, litter sifted, 6.VII.2016, leg. Assing \& Schülke (cAss, MNB); 2 우, ㄴ, WSW Kapan, S Meghri Pass, $39^{\circ} 05^{\prime} \mathrm{N}, 46^{\circ} 11^{\prime} \mathrm{E}, 2170 \mathrm{~m}$, oak forest margin, litter (partly moist litter under bushes) sifted, 8.VII.2016, leg. Assing (cAss); 1 ㅇ, S Martuni, Sulema Pass, 3958'N, $45^{\circ} 14^{\prime} \mathrm{E}, 2340 \mathrm{~m}$, slope with small stream and scattered bushes, litter and roots near stream sifted, 8.VII.2017, leg. Assing (cAss); 2 exs., same data, but 29.VI.2016, leg. Schülke (MNB); 3 exs., Lanjanist env., $39.86^{\circ} \mathrm{N}, 44.94^{\circ} \mathrm{E}$, $1560 \mathrm{~m}$, leaf litter and rotting wood sifted, 18.V.2015, leg. Kocian (cKoc); 8 exs., Yeghegis env., $39.87^{\circ} \mathrm{N}, 45.41^{\circ} \mathrm{E}$, 1700 m, deciduous forest, sifted, 20.V.2015, leg. Kocian (cKoc, cAss). Georgia: 2 exs., Kakheti, Pshaveli env., above Lechuri, $42.15^{\circ} \mathrm{N}, 45.41^{\circ} \mathrm{E}, 580 \mathrm{~m}$, deciduous forest, sifted, 14.VII.2015 (cKoc, cAss).

Comment: The above records are within the known range, which includes Armenia, Turkey, Iran, and Georgia. The currently known distribution is illustrated in Map 1.

\section{Sunius fulgocephalus (CoIfFAIt, 1970) (Map 2)}

Material examined: Armenia: 1 ex., Dashtakar env., bank of Vedi river, $39.02^{\circ} \mathrm{N}, 44.78^{\circ} \mathrm{E}, 1000 \mathrm{~m}, 18 . \mathrm{V} .2015$, leg. Kocian (cKoc).

Comment: This species is widespread in the Caucasus region (Armenia, Georgia, Azerbaijan, Iran). Its currently known distribution is illustrated in Map 2. 


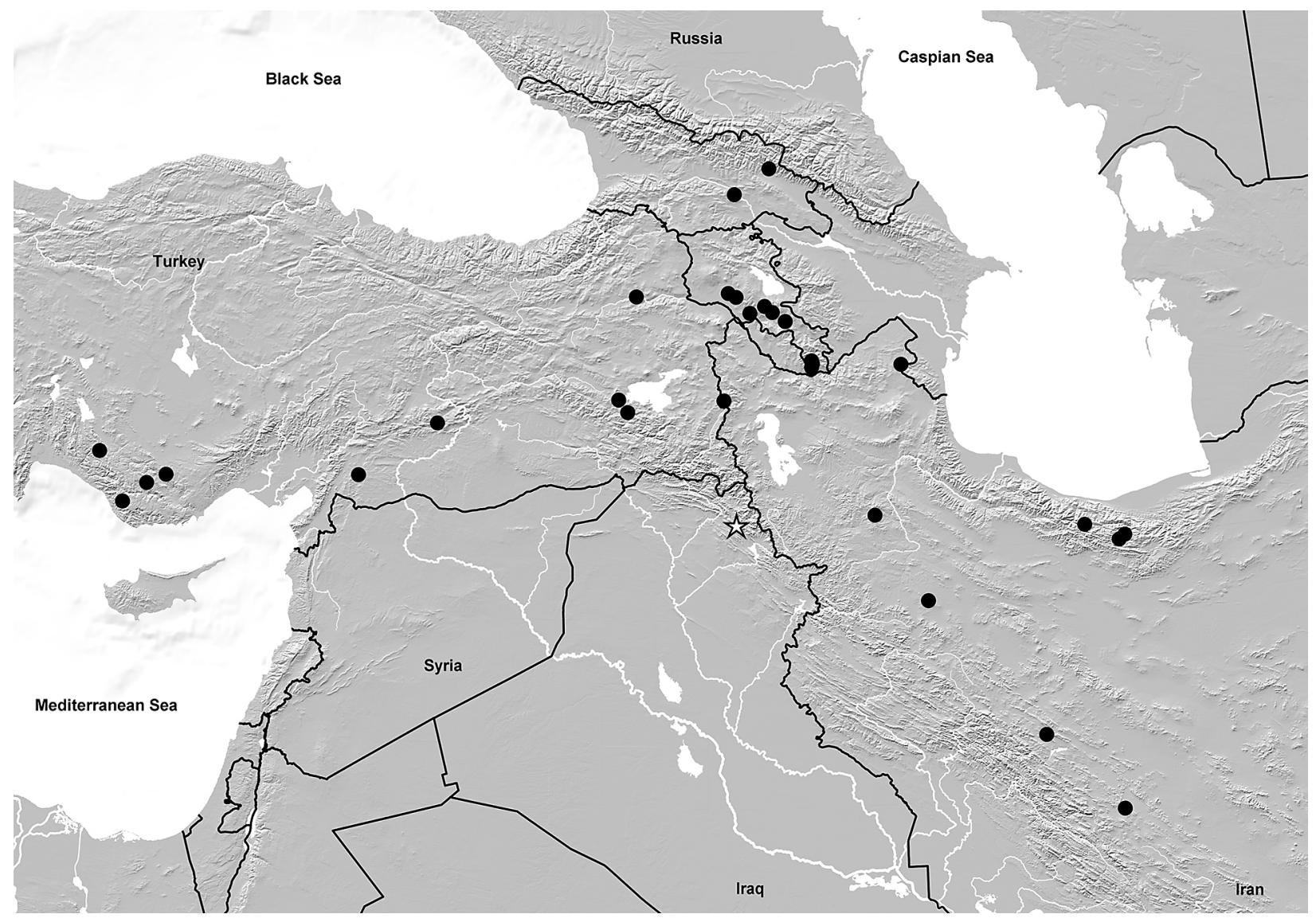

Map 1: Distributions of Sunius khnzoriani (black circles) and S. reuteri spec. nov. (open star) based on revised records.

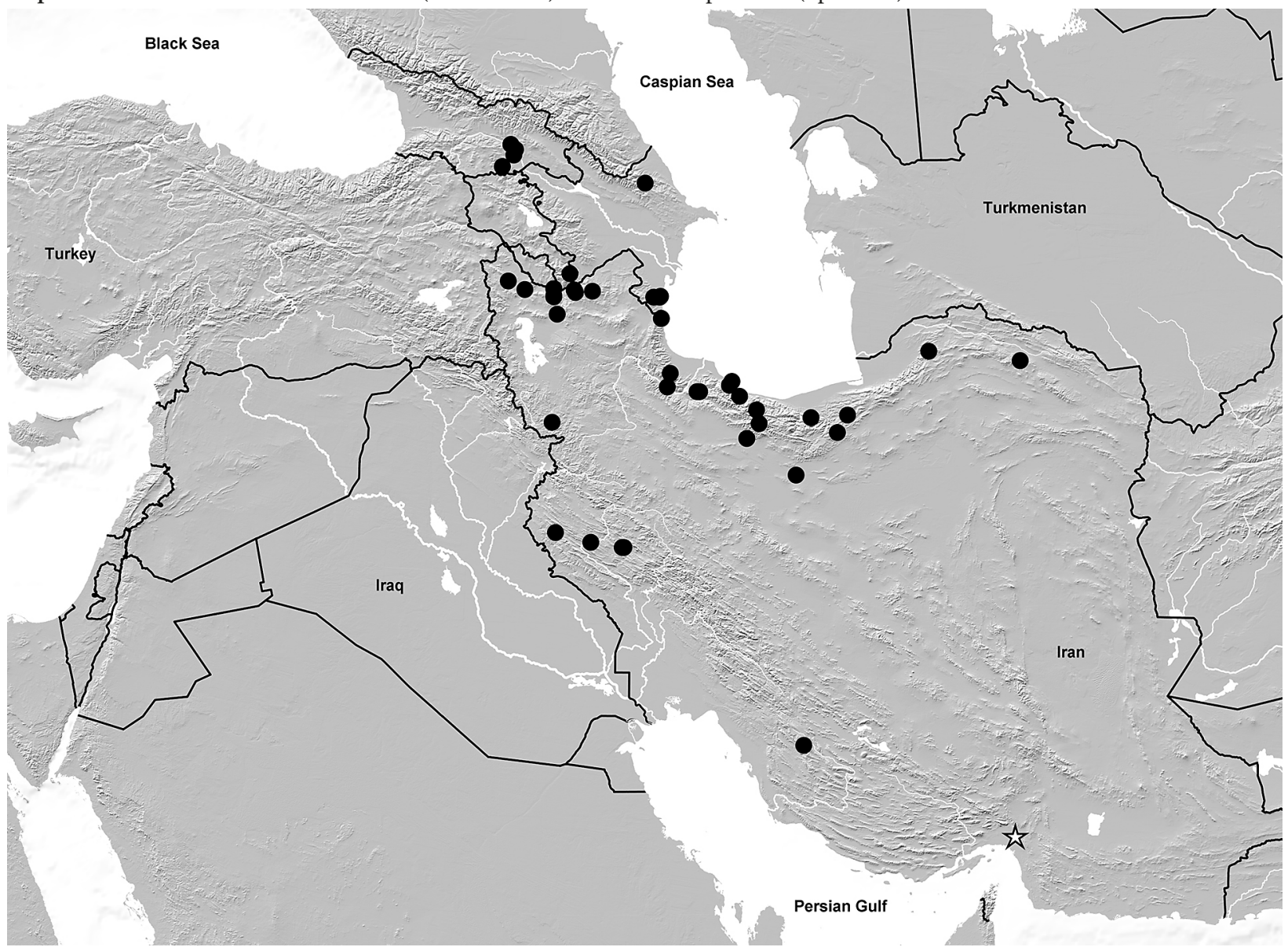

Map 2: Distributions of Sunius fulgocephalus (black circles) and S. concurvatus spec. nov. (open star) based on revised records. 
Sunius reuteri spec. nov.

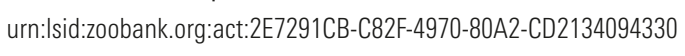

(Figs 1-3, Map 1)

Type material: Holotype $0^{\top}:$ "N-IRAQ, S Rawandoz, Akoian valley, $1400 \mathrm{~m}, \sim 36^{\circ} 30^{\prime} \mathrm{N}, 44^{\circ} 36^{\prime} \mathrm{E}, 17 .-25 . \mathrm{IV}$. 2017, pitfall trap, leg. Reuter / Holotypus ơ Sunius reuteri sp. n. det. V. Assing 2017” (cAss).

Etymology: The species is dedicated to Christoph Reuter, journalist and collector of the holotype, in appreciation of his efforts collecting Staphylinidae during his travels to regions that are practically inaccessible for most entomologists.

Description: Body length $3.8 \mathrm{~mm}$; length of forebody $1.8 \mathrm{~mm}$. Coloration: head dark-brown; pronotum and elytra reddish; abdomen blackish-brown; legs and antennae reddish.

Head (Fig. 1) approximately as long as broad; lateral margins behind eyes subparallel; punctation moderately coarse, rather dense in anterior portion and sparse in posterior portion of dorsal surface; interstices without microsculpture. Eyes of moderate size, approximately 0.7 times as long as postocular region in dorsal view. Antenna $1.1 \mathrm{~mm}$ long.

Pronotum (Fig. 1) approximately 1.05 times as long as broad and 0.95 times as broad as head; punctation dense, slightly finer than that of head; interstices without microsculpture; midline with broad impunctate median band.

Elytra (Fig. 1) 0.88 times as long as pronotum; punctation shallow, not very defined, and very dense. Hind wings reduced.

Abdomen broader than elytra; punctation dense and fine, only slightly sparser on posterior than on anterior tergites; interstices with very shallow microreticulation; posterior margin of tergite VII without palisade fringe. $\sigma^{*}$ : sternite VII unmodified; sternite VIII with broadly and rather deeply $\mathrm{V}$-shaped posterior excision, otherwise unmodified; aedeagus (Figs 2-3) $0.4 \mathrm{~mm}$ long; ventral process stout, subapically with acute lateral process in ventral view; internal sac with a pronounced rod-like structure.

Comparative notes: As can be inferred from the morphology of the aedeagus (shape of ventral process, internal sac with sclerotized rod-like structure), S. reuteri belongs to the $S$. melanocephalus group sensu lato, which includes the $S$. melanocephalus, S. adanensis, and S. bicolor groups (see Assing 2008, 2011) and which is represented in the Middle East and the Caucasus region by numerous externally similar species. It shares the subapical lateral projections of the ventral process of the aedeagus with some species of the $S$. adanensis group. Based on external characters, $S$. reuteri is indistinguishable from the micropterous morph of the widespread and geographically close S. khnzoriani. It differs from this and other species of the S. melanocephalus group sensu lato by the shape of the ventral process of the aedeagus (both in lateral and in ventral view) and by the shape of the rod-like structure in the internal sac, from most species also by the absence of a distinct palisade fringe at the posterior margin of tergite VII.

Distribution and natural history: The type locality is situated in Northeast Iraq, approximately $65 \mathrm{~km}$ to the northeast of Arbil (Map 1). The holotype was collected with pitfall traps on a calcareous slope with small oak trees, bushes and grass (REUTER pers. comm.) at an altitude of approximately $1400 \mathrm{~m}$ (Fig. 10).

\section{Sunius mordicus AssING, 2008}

Material examined: Kazakhstan: $1 o^{*}$, Dshanbul mountains, Kurdai pass, 1000 m, 3.VIII.1995, leg. Lukhtanov (NMP).

Comment: This species is widespread and not uncommon in Middle Asia. Its distribution is mapped in Assing (2008).

\section{Sunius extensissimus Assing, 2011}

Material examined: Oman: 1 ex., NE-Oman, 10 km SE Sur, 14.III.2015, leg. Snižek (NME).

Comment: The original description is based on a unique male from Oman (Assing 2011). The above specimen represents the second record of this species.

\section{Sunius concurvatus spec. nov.

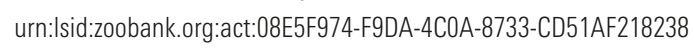 (Figs 4-9)}

Type material: Holotype $\sigma^{*}$ : "S-IRAN, Prov. Hormozgan, Gur Band, Berghänge und Tal mit Staubecken, 50 m, $27^{\circ} 19^{\prime} 05^{\prime \prime N}$, 5700'22"E, 4.III.2014, leg. D. Frenzel /96 / Holotypus o Sunius concurvatus sp. n. det. V. Assing 2015” (NME).

Etymology: The specific epithet is the past participle of the Latin verb concurvare (to bend) and alludes to the strongly bent ventral process of the aedeagus in lateral view.

Description: Body length $3.8 \mathrm{~mm}$; length of forebody $2.1 \mathrm{~mm}$. Coloration: head and pronotum reddish; elytra yellowish; abdomen dark brown anteriorly, gradually becoming paler towards apex; legs yellowish; antennae and maxillary palpi pale-reddish.

Head (Fig. 4) approximately as long as broad; lateral margins behind eyes subparallel; punctation coarse and dense, only slightly sparser in median dorsal portion; 


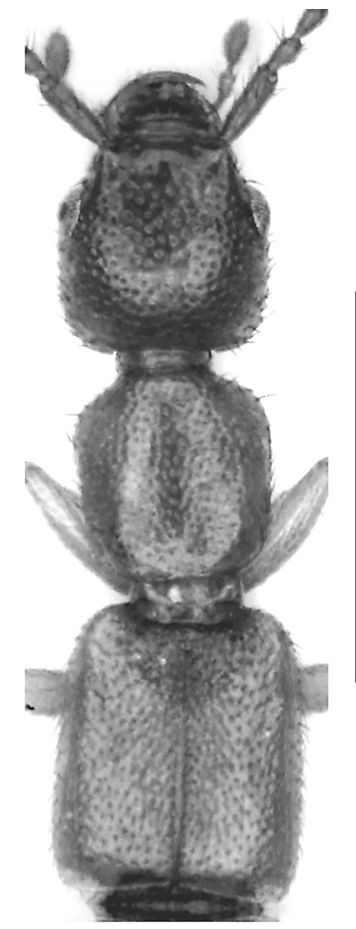

4

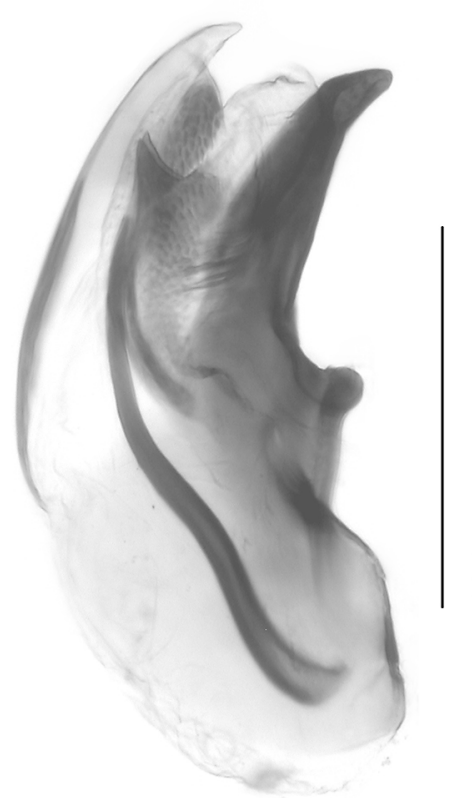

2

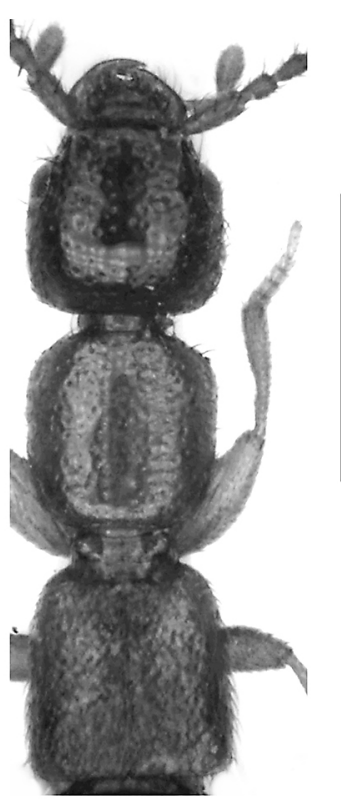

1

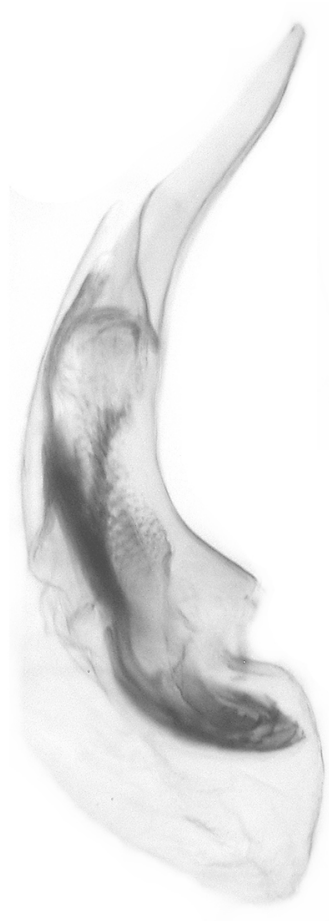

7

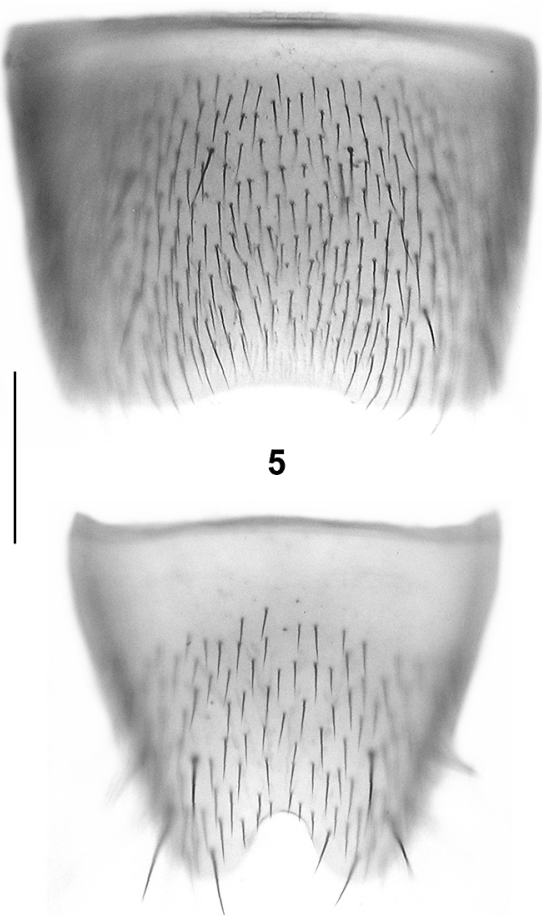

6

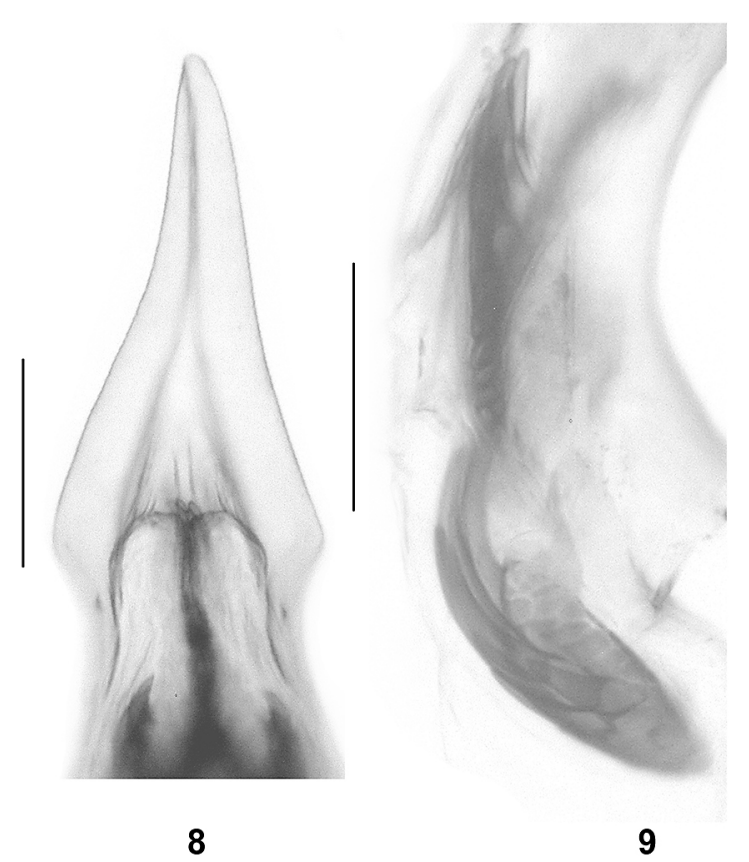

Figs 1-9: Sunius reuteri spec. nov. (1-3) and S. concurvatus spec. nov. (4-9): forebody $(1,4)$; aedeagus in lateral and in ventral view $(2-3,7)$; male sternite VII (5); male sternite VIII (6); apical portion of ventral process of aedeagus in ventral view (8); internal structures of aedeagus in lateral view (9). Scale bars: 1, 4: 1.0 mm; 2-3, 5-7: 0.2 mm; 8-9: 0.1 mm.

interstices without microsculpture. Eyes rather small, slightly more than half as long as postocular region in dorsal view. Antenna $1.2 \mathrm{~mm}$ long.

Pronotum (Fig. 4) 1.09 times as long as broad and 0.9 times as broad as head; punctation denser and distinctly finer than that of head; interstices without microsculpture; midline without impunctate median band.
Elytra (Fig. 4) 1.1 times as long as pronotum; punctation shallow, not very defined, and very dense. Hind wings fully developed.

Abdomen approximately as broad as elytra; punctation dense and distinct on anterior tergites, gradually becoming finer and less dense towards posterior tergites; interstices with distinct microreticulation; posterior margin of tergite VII with palisade fringe. 


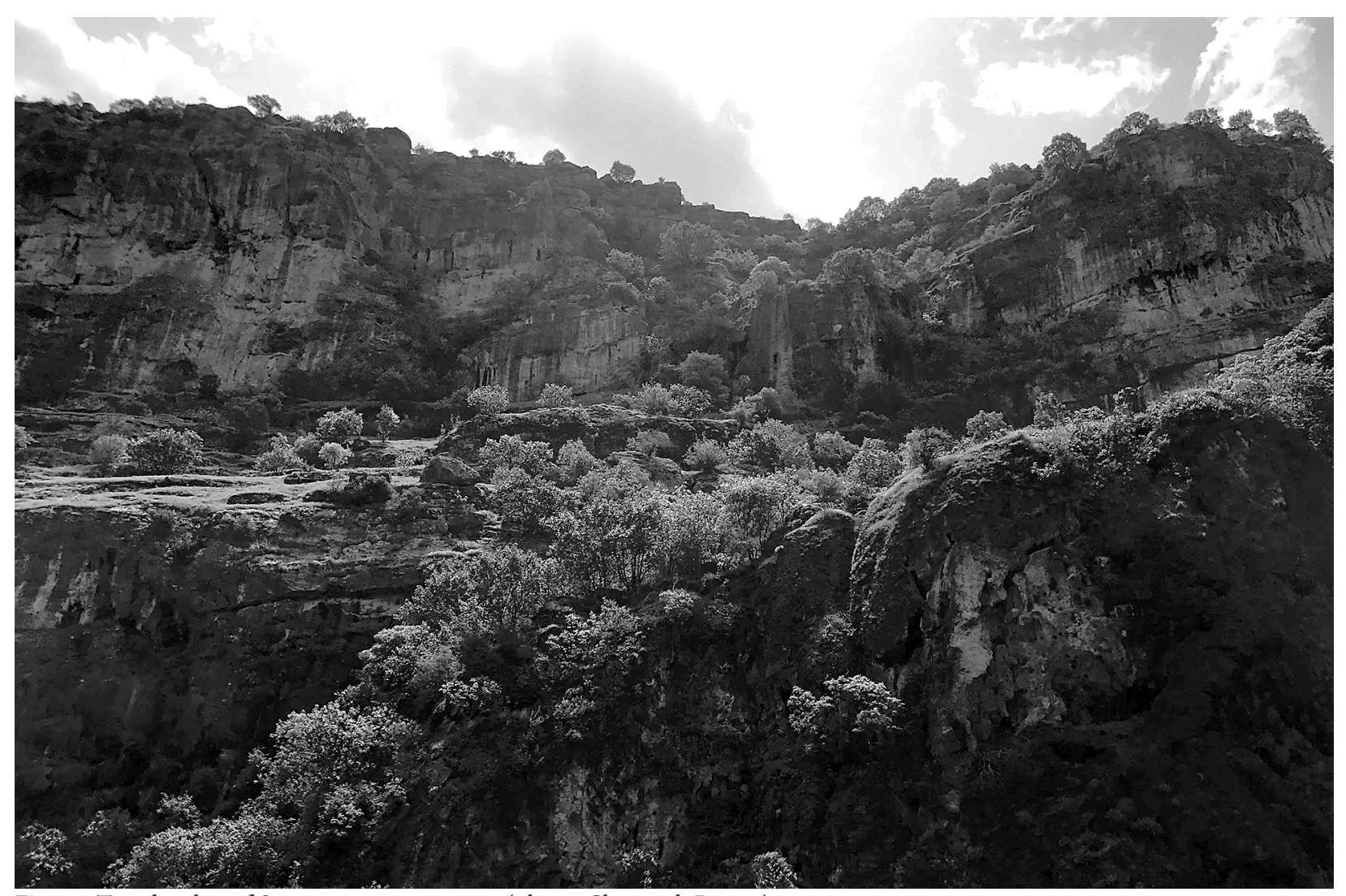

Fig. 10: Type locality of Sunius reuteri spec. nov. (photo: Christoph Reuter).

$0^{7}$ : sternite VII (Fig. 5) 1.4 times as broad as long, posterior margin with shallow, but distinct concavity in the middle; sternite VIII (Fig. 6) weakly transverse, pubescence unmodified, posterior excision 0.18 times as deep as length of sternite; aedeagus (Figs 7-9) $0.6 \mathrm{~mm}$ long; ventral process strongly curved and apically acute in lateral view, distinctly asymmetric in ventral view; internal sac with two pronounced clusters of sclerotized spines, those of the basal cluster longer and more numerous.

Comparative notes: Based on the external (habitus, punctation) and the male sexual characters (shapes of sternites VII and VIII; shape and internal structures of the aedeagus), S. concurvatus belongs to the S. viator group and is most similar to S. basalis (ReItTer, 1899), which too has been recorded from South Iran. It differs from $S$. basalis by a more oblong and broader head with more regular and coarser punctation, longer and broader, uniformly yellowish elytra (bicoloured with the anterior third infuscate in S. basalis), as well as by a more strongly curved (lateral view) and more slender (both in lateral and in ventral view) ventral process of the aedeagus (lateral view). For illustrations and a description of $S$. basalis see Assing (2008, 2011).

Distribution and natural history: The type locality is situated in Hormozgan province in southern Iran. The holotype was collected at an altitude of only $50 \mathrm{~m}$.

\section{Acknowledgements}

The colleagues indicated in the material section provided the material which this study is based on. I am much indebted to Benedikt Feldmann (Münster) for the generous gift of the holotype of Sunius reuteri, as well as for proof-reading the manuscript.

\section{References}

Anlaş, S. 2015a: On the genus Sunius Curtis, 1829 [sic] of Turkey I. Two new micropterous species from central western Turkey (Coleoptera: Staphylinidae, Paederinae). - _ Turkish_ _ournal of Zoology 39: 799-803 - DOI: '10.3906/zoo-1407-21

AnLAş, S. 2015b: Ōn the genus Sunius CurTis, 1829 [sic] of Turkey II. Two new micropterous species and additional records from Western Anatolia (Coleoptera: Staphylinidae: Paederinae). - Zootaxa 3985(4): 493-498 - DOI:'10.11646/zootaxa.3986.4.9."

Anlaş, S. 2016a: On the genus Sunius CurTis, 1829 [sic] of Turkey III. Four new species from western Anatolia (Coleoptera: Staphylinidae: Paederinae). - Zoology in the Middle East 62(1): 68-77 - DOI: $10.1080 / 09397140.2016 .1144275$ 
Anlaş, S. 2016b: On the genus Sunius CurTis, 1829 [sic] of Turkey IV. A new micropterous species from southwestern Anatolia and additional records (Coleoptera: Staphylinidae: Paederinae). - Revue Suisse de Zoologie 132(2): 303-306 - DOI: 10.5281/, zenodo.155304

Assing, V. 2008: A revision of the Sunius species of the Western Palaearctic region and Middle Asia (Coleoptera: Staphylinidae: Paederinae). _- Linzer Biologische Beiträge 40(1): 5-135 _ - http://www: zobodat.at/pdf/LBB_0040_1_0005-0135.pdf [accessed 2017/10/23].

Assing, V. 2011: The Sunius species of the Palaearctic region (Coleoptera: Staphylinidae: Paederinae)._Linzer Biologische Beiträge 43(1): 151-193 - 'http:// www.zobodat.at/pdf/LBB_0043_1_0151-0193.pd df [accessed $2017 / 10 / 23]$.
Assing, V. 2015: A revision of Sunius XV. Six new species from Kyrgyzstan and the Himalaya, and additional records (Coleoptera: Staphylinidae: Paederinae). Contributions to Entomology 65(2): 287-295 - DOI: '10.21248/contrib.entomol.65.2.287-295!.

Assing, V. 2016: On the Staphylinidae of the Greek island Lesbos II, with supplementary notes on the fauna of Samos and Chios (Coleoptera: Staphylinidae). Koleopterologische Rundschau 86: 103-138. 


\section{Besprechung / Review}

WILLNER, W. 2017: „Taschenlexikon der Schmetterlinge Europas - Alle Tagfalter im Porträt“. - Quelle \& Meyer, Wiebelsheim: 450 S. - ISBN 978-3-494-01633-7.

Wenn man dieses Buch oberflächlich durchblättert, dann hinterlässt es einen guten Eindruck. In einer recht knappen Einleitung werden Tagfalter kurz eingeführt, erst ihr Körperbau, dann ihre unterschiedlichen Stadien und ihre Lebensweise. Anschließend werden noch einige wichtige Lebensräume vorgestellt und dann wird auf Gefährdung und Schutz eingegangen. Auf den sich anschließenden fast 400 Seiten wird ein erheblicher Teil der europäischen Tagfalterarten vorgestellt, meist mit einem oder mehreren schönen Falterbildern im Freiland, in manchen Fällen sogar mit einem Raupenbild. Der Text beschreibt erst die Morphologie der Falter und gibt dann Informationen zur Ökologie, vor allem den Raupenfraßpflanzen, und der Verbreitung. Für die auch in Deutschland vorkommenden Arten werden, sofern vorhanden, die Rote-Liste-Einstufung sowie Rückgangsgründe angegeben.

Schaut man sich dieses Buch dann aber genauer an, dann verschwindet dieser am Anfang positive Grundeindruck schnell. Das fängt schon damit an, dass es zwar immer einen Balken mit Angaben zur Flugzeit gibt, die zweite Leiste $\mathrm{zu}$ den Raupen ist mal da, mal nicht; und das ganze scheint irgendwo rein zufällig. Auch die Angabe der deutschen Roten Liste scheint bei einem Buch über die europäischen Tagfalter wenig sinnvoll, insbesondere wenn hierbei noch Fehler unterlaufen. So ist Papilio alexanor mit Vorwarnliste angegeben. Die nächsten Vorkommen zu Deutschland befinden sich jedoch in der Provence ... Generell wird mit den Angaben zur Verbreitung sehr lax umgegangen. Diese sind zum Teil irreführend oder sogar schlichtweg falsch. So kann man, wenn man Iphiclides feisthamelii als Art endemisch für Iberien akzeptiert für Iphiclides podalirius nicht auch die Iberische Halbinsel angeben; beide Taxa schließen sich weitgehend aus! Verwirrend ist auch die Angabe für den Osterluzeifalter: „Vom östlichen Mittelmeergebiet über die französischen Meeralpen, Italien bis nach Österreich, den Balkan und Griechenland“. Auch sehr fragwürdig ist, dass der Autor manchmal angibt, dass sich seine Beschreibung nur auf den europäischen Teil des Areals bezieht, manchmal nicht. Bei einer Art wie Zerynthia rumina, für die angegeben wird: „Iberische Halbinsel und französische Mittelmeerküste" fragt man sich dann ohne Hintergrundwissen, ob die Art wirklich nur dort vorkommt. Schon ist man auf die fragwürdigen Angaben des Autors reingefallen, denn die Art, die auch noch "Spanischer Osterluzeifalter" genannt wird, ist im Maghreb weit verbreitet. So könnte man nun fast beliebig fortfahren.
Die optisch schönen Abbildungen darf man als Tagfalterkenner nicht genau ansehen, denn die Anzahl an Bestimmungsfehlern ist enorm! Rein beim Durchblättern habe ich folgende Fehler gesehen, und weitere Bestimmungen bei schwierigeren Arten schienen mir fragwürdig. Auf Seite 80 ist Thymelicus lineola abgebildet, nicht Th. sylvestris, die schwarzen Fühlerkolben sind klar erkennbar. Das obere Bild auf Seite 144 ist niemals Aricia artaxerxes sondern ein PolyommatusWeibchen. Das Weibchen von Lycaena thersamon auf Seite 178 ist für mich ein Lycaena tityrus. Die Polyommatus coridon-Kopula auf Seite 204 sieht für mich sehr nach Polyommatus icarus aus; im Austausch dafür sind die beiden Polyommatus eros auf Seite 212 aber lupenreine Polyommatus coridon. Für die drei Polyommatus icarus auf Seite 220 liegt die Trefferquote bei 33\%, zwei sind das nämlich nicht, der Falter rechts unten etwa ist klar Polyommatus semiargus. Auf Seite 258 unten ist nicht Argynnis laodice abgebildet sondern Argynnis pandora. Im Ausgleich sollte die Abbildung auf Seite 260 unten nicht Argynnis pandora sein, sondern die valesina-Form des Kaisermantels. Boloria napaea auf Seite 270 ist Boloria pales, dafür ist auf der nächsten Seite unten anstatt Boloria pales ein eindeutiger Boloria napaea abgebildet. Der Brenthis daphne auf Seite 277 sieht für mich wie ein Argynnis aus. Dann kommt das Drama bei den Mohrenfaltern: Erebia mnestra auf Seite 318 sollte ein Vertreter der E. tyndarus-Gruppe sein, E. montana auf Seite 319 ist E. gorge, E. neoridas auf Seite 320 ist E. aethiops, E. nivalis auf derselben Seite ist E. pronoe, und auch das schlechte Bild auf Seite 329 ist nicht E. styx. Weiter scheint mir Lasiommata petropolitana auf Seite 364 doch eher Lasiommata maera zu sein. Die Gattung Melitaea ist kniffelig, aber die Unterseite auf Seite 384 ist definitiv keine Melitaea aurelia. Die Kopula von Melitaea didyma auf Seite 390 ist Melitaea cinxia. Bei Melitaea ornata wird im Text auf die Verwechslungsmöglichkeit mit Melitaea phoebe verwiesen, das Bild belegt, dass es schwierig ist, denn es scheint mir eine Verwechslung vorzuliegen, aber mit Melitaea aetherie. Pararge xiphia auf Seite 410 ist nicht der Madeiraendemit sondern die ganz gewöhnliche Pararge aegeria, die mittlerweile auf Madeira die endemische Art fast verdrängt hat.

Kurzes Fazit: Leider ist dieses auf den ersten Blick ansprechende Buch voller Fehler und Unzulänglichkeiten. Gerade für den Nichtspezialisten, für den es geschrieben ist, wird es eher größere Verwirrung erzeugen und ihm viele Fehler beibringen, statt ihm bei der Bestimmung zuverlässig zu helfen. So sehr es mich persönlich schmerzt, denn der Autor hat sicher viel Zeit, Engagement und Herzblut investiert, ich kann dieses Taschenlexikon nicht empfehlen. 